\title{
Application of the Technology Acceptance Model and the Technology-Organisation-Environment Model to examine social media marketing use in the South African tourism industry
}

\begin{tabular}{|c|c|}
\hline \multicolumn{2}{|c|}{$\begin{array}{l}\text { Authors: } \\
\text { Rosemary Matikiti } \\
\text { Mercy Mpinganjira }^{1} \\
\text { Mornay Roberts-Lombard }^{1} \text { (†) }\end{array}$} \\
\hline \multicolumn{2}{|c|}{$\begin{array}{l}\text { Affiliations: } \\
\text { 'Department of Marketing } \\
\text { Management, University of } \\
\text { Johannesburg, South Africa }\end{array}$} \\
\hline \multicolumn{2}{|c|}{$\begin{array}{l}\text { Corresponding author: } \\
\text { Rosemary Matikiti, } \\
\text { matikiti@gmail.com }\end{array}$} \\
\hline \multicolumn{2}{|c|}{$\begin{array}{l}\text { Dates: } \\
\text { Received: } 12 \text { Sept. } 2016 \\
\text { Accepted: } 05 \text { Sept. } 2017 \\
\text { Published: } 04 \text { Apr. } 2018\end{array}$} \\
\hline \multicolumn{2}{|c|}{$\begin{array}{l}\text { How to cite this article: } \\
\text { Matikiti, R., Mpinganjira, M. } \\
\text { \& Roberts-Lombard, M., } \\
\text { 2018, 'Application of the } \\
\text { Technology Acceptance } \\
\text { Model and the Technology- } \\
\text { Organisation-Environment } \\
\text { Model to examine social } \\
\text { media marketing use in the } \\
\text { South African tourism } \\
\text { industry', South African } \\
\text { Journal of Information } \\
\text { Management 20(1), a790. } \\
\text { https://doi.org/10.4102/ } \\
\text { sajim.v20i1.790 }\end{array}$} \\
\hline \multicolumn{2}{|c|}{$\begin{array}{l}\text { Copyright: } \\
\text { ๔ 2018. The Authors } \\
\text { Licensee: AOSIS. This } \\
\text { is licensed under the } \\
\text { Creative Commons } \\
\text { Attribution License. }\end{array}$} \\
\hline \multicolumn{2}{|l|}{ Read online: } \\
\hline 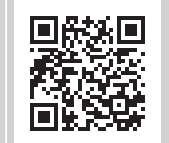 & $\begin{array}{l}\text { Scan this QR } \\
\text { code with your } \\
\text { smart phone or } \\
\text { mobile device } \\
\text { to read online. }\end{array}$ \\
\hline
\end{tabular}

Background: In tourism, globally there is a growing interest in social media marketing research. However, most previous research on social media marketing has focused on large tourism enterprises such as chain hotels, leaving out small tourism businesses such as travel agencies and tour operators.

Objective: The aim of this research was to establish factors that influence attitude towards the use of social media marketing by travel agencies and tour operators in South Africa.

Method: The study adopted a quantitative approach through the use of questionnaires. Data used in the analysis were collected from 150 travel agencies and tour operators by means of a structured questionnaire. Multiple regression analysis and one-way ANOVA were used for data analysis.

Results: The results showed that managerial support and managers' level of education are the two main internal factors which influence attitude towards the use of social media marketing. Pressure from competitors, perceived benefits and perceived ease of use were found to be the most prominent external factors which influence the use of social media marketing. The results also revealed that technical knowledge moderates the relationship between attitude towards social media marketing and the level of social media marketing usage.

Conclusion: The study concludes with these recommendations: Management of travel agencies, tour operating businesses and the South African government should support the use of social media marketing by small tourism businesses through providing training and workshops on social media marketing for the employees to acquire the required skills.

\section{Introduction}

The development of the Internet and its related technologies, such as social media platforms, has rapidly changed the manner in which people communicate with each other. The consumer today prefers using online channels to traditional channels (Aspasia \& Ourania 2014). In the last two decades growing numbers of companies and enterprises have adopted electronic communications to conduct their marketing activities, thereby providing a platform for e-marketing to grow at a faster rate (El-Gohary 2012). Social media has revolutionised the way in which marketing activities are performed (Ndekwa \& Katunzi 2016).

Social media, as defined by Kaplan and Haenlein (2010:61), is 'a group of Internet-based applications that build on the ideological and technological foundations of Web 2.0 that allow the creation and exchange of User Generated Content'. The main benefits of using social media marketing, according to the literature, include reducing administrative cost, increasing awareness (Jones, Borgman \& Ulusoy 2015), enabling small businesses to compete with large businesses and to access global markets (Ndekwa \& Katunzi 2016), enabling 24/7 operations to be provided, thereby overcoming the time limitations and being less expensive and not complex to implement (Kim, Lee \& Lee 2011). Small businesses can easily utilise it. Despite all these benefits, Verheyden and Goeman (2013) concluded that large tourism enterprises are adopting more social media technologies than small tourism businesses, and that social media marketing is a recent concept to small tourism businesses (Chmielecki 2014). 
In South Africa, most travel agencies and tour operators are classified under small and medium-sized enterprises (SMMEs), which represent a significant part of the country's economy. While statistics cannot be found on the contribution made only by travel agents and tour operators, 679500 jobs were directly generated in 2014 by the travel and tourism industry in South Africa, according to the 2015 report of the World Travel and Tourism Council. This number includes job opportunities created by hotels, travel agencies, tour operators, airlines and transportation services related to tourism (World Travel and Tourism Council 2015). In addition, travel and tourism contributed $4.6 \%$ to the South African gross domestic product (World Travel and Tourism Council 2015).This shows that the tourism industry is playing an important role in the South African economy. If more tourism businesses are able to adopt social media marketing, their marketing effort will be enhanced, and this, in turn, can improve their customer base, resulting in more profits. Despite the importance of SMMEs to the country's economy and the great benefits associated with social media marketing, little attention has been given to establishing how these small tourism businesses in South Africa utilise social media technologies for marketing. There is nevertheless growing interest in social media marketing research in tourism globally. However, most studies (Meske \& Stieglitz 2013; Seth 2012; Yazdanifard \& Yee 2014) focus on large tourism enterprises such as chain hotels, and there is little research on the utilisation of social media by SMMEs in the tourism industry specifically (Abou-Shouk, Lim \& Megicks 2016). Most previous work has been conducted in developed nations, and little attention has been paid to developing nations such as South Africa. Recent marketing research on travel agencies by Viljoen and Roberts-Lombard (2016) focused on reintermediation strategies for disintermediated travel agencies. No research study could be found that focused on the state of social media marketing implementation in travel agencies and tour operators in South Africa. There is thus a gap in the literature which needs to be covered, and a study is required to address this issue in the context of both Africa and emerging markets.

This study explores factors which influence the utilisation of social media marketing by travel agencies and tour operators in South Africa. To achieve this, the study adopted the Technology Acceptance Model (TAM) and the TechnologyOrganisation-Environment (TOE) framework.

\section{Problem statement}

Social media marketing, according to Kim et al. (2011), is relatively inexpensive and not difficult to implement. Thus, SMMEs can adopt social media technologies without using large sums of money. Adoption of social media marketing can give SMMEs an opportunity to access markets previously dominated by large businesses (Sago 2013). Meske and Stieglitz (2013) argue that 'SMMEs should quickly grab social media and (re)-design their marketing strategies'. However, SMMEs often lag behind large companies in adopting social media technologies (Meske \& Stieglitz 2013). Little has been done so far to establish the reasons why SMMEs in the tourism industry are lagging behind in the adoption of new Internet platforms such as social media (Abou-Shouk et al. 2016). More precisely, little research attention has been paid to the state of adoption and utilisation of social media marketing in emerging economies such as South Africa. In the new millennium where most customers rely on social media sites to search for travel information, only those companies which are up to date with social media marketing strategies will have a competitive edge. Establishing factors that influence social media adoption will assist in making proper recommendations for improving the uptake of social media marketing. Considering this, Sago (2013) states that:

understanding factors that influence the adoption of social media services can assist tourism marketers in selecting the appropriate social media to use and how to best structure their social media content. (p. 3)

\section{Purpose and objectives}

In view of the research problem above, this study aimed to explore the factors which influence attitude towards the use of social media marketing by small tourism business in South Africa. The following secondary objectives support the primary aim of the article:

- to explore the internal factors which influence attitude towards the adoption of social media marketing by travel agencies and tour operators in South Africa;

- to investigate the external factors which influence attitude towards social media marketing adoption by travel agencies and tour operators in South Africa;

- to ascertain whether technical knowledge moderates the relationship between attitude towards social media marketing adoption and the level of social media marketing usage;

- to make recommendations regarding the relationship between level of social media marketing usage and intention to continue using social media marketing.

\section{Literature review and hypothesis development}

This section briefly discusses the theories commonly used in explaining the adoption and implementation of new Internet technologies. It also focuses on current literature relating to social media marketing in tourism services and on factors relating to attitude towards the use of social media marketing.

\section{Social media marketing in tourism services}

Social media are considered 'as disruptive information technology (IT) innovations that have the capabilities of transforming the way we are currently doing business' (Wamba \& Carter 2014:15). Social media marketing can promote social interaction between businesses and customers through social media platforms such as blogs, Facebook, Twitter and many other social networking sites (Järvinen et al. 2012). 'In the 21st century tourism promotion has entered a new era as social media has become a powerful tool to promote tourism in every country, region, state or destination' (Kirtis \& Karahan 2011:262). Social media is the 
most profound development in the traditional marketing of tourism businesses (Järvinen et al. 2012). Social media makes communication easy. Indeed, it is becoming one of the most effective tools used by tourists to search for travel information and exchange their travelling encounters (Cox 2010). For SMMEs, social media marketing is a way to go as it does not need more sophisticated infrastructure, what is needed, is only a device which can access Internet and the Internet connections (El-Gohary 2012). These SMMES can afford with limited costs. The 'viral feature' of social media makes it especially suitable for the tourism business environment. Tourism marketers and other advertisers, as stated by Kirtis and Karahan (2011:236), 'have carried out their promotions through social media to take high attention and participation by consumers to maximize their brand exposure'. Consequently, it has become an important tool to communicate and get feedback from customers globally.

The Technology Acceptance Model and the TechnologyOrganisation-Environment framework are the most common models used to explain the adoption and implementation of Internet technologies (Salwani et al. 2009). This study also employed both models to explore the adoption of social media marketing in tourism. The next sections explain these models.

\section{Technology Acceptance Model}

This model was originally proposed by Davis in 1989 and has become the most widely used model to explain user acceptance of new technologies. TAM was developed from the Theory of Reasoned Action (Fishbein \& Ajzen 1975) and provides a basis for tracing how external variables influence belief, attitude and intention to use new technologies $(\mathrm{Wu}, \mathrm{Li}$ $\& \mathrm{Fu}$ 2011). TAM reflects the fact that the actual use of a new technology depends upon the user's attitude towards that technology, the perceived ease of use of the technology, and the perceived benefits that can be derived from using it (shown in Figure 1). Behaviour is thus predicted using the two variables of perceived ease of use and perceived usefulness (Fishbein \& Ajzen 1975). From this model, it is deduced that whenever an individual perceives that using a certain technology will assist in improving performance or will bring some benefits to the company, the individual will be eager to adopt it. At the same time, if the new technology is perceived to be easy to implement, people will not hesitate to adopt it. Thus, if SMMEs understand the benefits of using social media marketing and if they have the ability to utilise it without any challenges they can more easily accept social media marketing (Salwani et al. 2009). The model has been

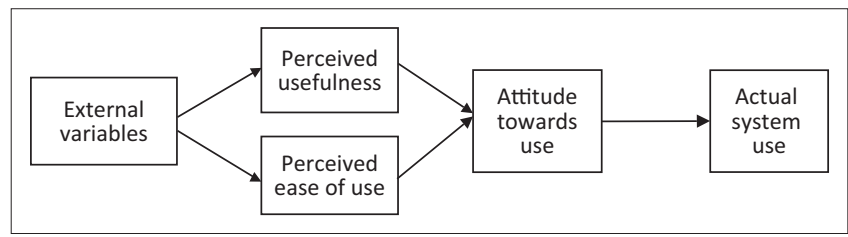

Source: Adapted from Davis, F.D., 1989, 'Perceived usefulness, perceived ease of use and user acceptance of information technology', MIS Quarterly 13(2), 319-340. https://doi. org $/ 10.2307 / 249008$

FIGURE 1: Technology Acceptance Model. used to predict the acceptance of new IT and has proved to be reliable in explaining acceptance behaviour in some areas of information systems (El-Gohary 2012; Wu et al. 2011). In this study, TAM will be used in conjunction with TOE to establish which factors influence the use of social media marketing in small tourism business.

\section{The Technology-Organisation-Environment framework}

Technology-Organisation-Environment is an organisational level theory used to understand the role of three important components of a firm which can affect new technology implementation decisions. After realising the usefulness of technology adoption, Tornatzky and Fleischer (1990) proposed the TOE model to assess factors which can influence the adoption of new technology. The TOE model identifies three important aspects of an organisation that influence the process of technology adoption and implementation (Tornatzky \& Fleischer 1990), namely, technological context, organisational context and environmental context (see Figure 2).

The 'technological context' refers to internal and external technologies useful to the firm. These are 'current practices and equipment internal to the firm' (Starbuck 1976:183), including some available technologies which are outside the firm (Thompson 1967). The technological context can also denote the relevant skills required to use that particular technology (Thompson 1967). In this study, technological context was described as the technical knowledge required to implement social media marketing.

The 'organisational context' includes 'resources of the firm, linking structures between employees, intra-firm communication processes, firm size, and the amount of slack resources' (Oliveira \& Martins 2011). Specifically, it describes the size and scope of an organisation and the structure of management (Oliveira \& Martins 2011).

The 'environmental context' denotes the external aspects that influence a firm's decision to adopt new technologies, which include competitors, customers and government involvement. Thus, the TOE model provides a platform for

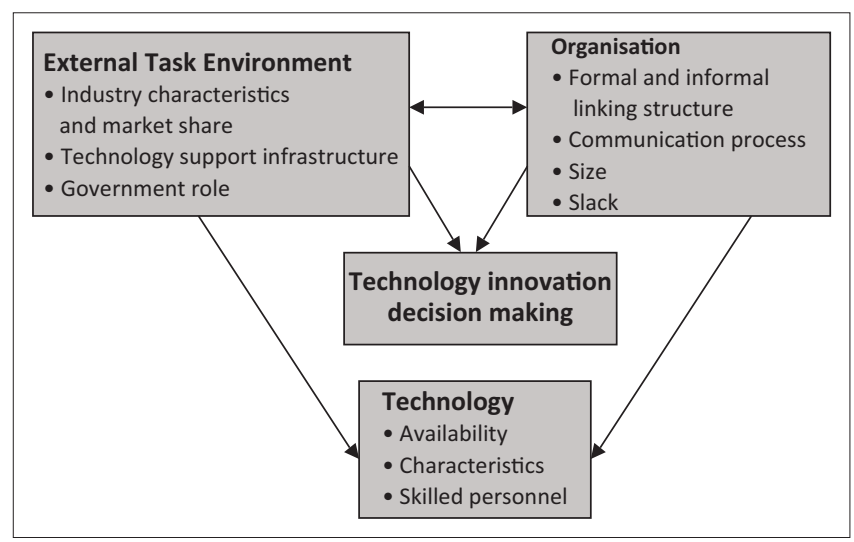

Source: Baker, F., 2012, 'The Technology-Organization-Environment framework', in Y.K. Dwivedi, M.R. Wade \& S.L. Schneberger (eds.), Information systems theory: Explaining and predicting our digital society, vol. 1, pp. 231-245, Springer, New York.

FIGURE 2: Technology-Organisation-Environment framework. 
assessing the adoption of social media marketing; in that it highlights both the internal (e.g. technical knowledge) and the external aspects (e.g. pressure from competitors) of an organisation which can influence the adoption of new technologies (Chao \& Chandra 2012). For instance, if an organisation does not have required skills to perform social media marketing, it will be difficult for it to adopt social media marketing even if there is pressure to do so from the external environment. At the same time what happens in the external environment can also affect the adoption of social media marketing. For instance, if an organisation's competitors are adopting or have adopted social media marketing, it will be forced also to adopt it to remain competitive (Wamba \& Carter 2014). Thus, TOE and TAM models provide a framework necessary for assessing new technology adoption such as social media.

Salwani et al. (2009) used TOE to investigate e-commerce usage by tourism businesses, while Hoti (2015) used TOE to investigate information systems. TOE has also been used to explain the adoption of IT (Chao \& Chandra 2012), as well as enterprise systems and social media (Wamba \& Carter 2014). In all these previous studies, technological, organisational and environmental factors have been shown to influence the way new technology adoption decisions are made.

From TAM and TOE, 10 factors were found to have an important influence on the use of social media marketing by small tourism businesses. From TAM, three factors were borrowed, namely perceived ease of use, perceived usefulness, and attitude, while the factors borrowed from TOE were managerial support, manager's level of education, manager's age, time, technical knowledge, pressure from customers, and competitors. The following section explains the factors and how the hypotheses were formulated, starting with top management support.

\section{Top management support}

The e-marketing adoption process in most SMMEs is influenced by top management, as they make all decisions concerning the adoption and future adoption of new technologies (Nguyen 2009). According to Dahnil et al. (2014), the top management has an influence on the availability of all resources required for implementing e-commerce projects. Managers who are up to date with emerging technology and are 'positively disposed towards e-commerce deployment support the innovations'(Tarafdar \& Vaidya 2006). Studies by Salwani et al. (2009) and Matikiti, Afolabi and Smith (2012) revealed that top management's support is an important factor which determines the adoption and implementation of new Internet technologies. It is thus posited in this study that:

$\mathbf{H}_{1}$ : Managerial support influences attitude towards social media marketing adoption.

\section{Manager characteristics (age and level of education)}

Age and education level are the two main characteristics which have been reported to influence the adoption and usage of new technologies (Aspasia \& Ourania 2014).The level of knowledge and skills one has regarding the use of a particular technology determines one's attitude towards that technology. According to Rogers (1995:120), 'early adopters of new technologies tend to have higher educational levels'. Porter and Donthu (2006:1000) indicated that older people do not have sufficient experience in using the Internet and its related technologies and 'it is likely that they have selfefficacy concerns related to learning how to use the Internet'. Aspasia and Ourania (2014) and Wamba and Carter (2014) concluded that managers' level of education has a significant impact on the adoption of social media tools. On the other hand, Gong (2012) could not find any relationship between level of education and attitude towards using social media sites. It is expected in this study that:

$\mathbf{H}_{2}$ : The age of the manager influences attitude towards social media marketing adoption.

$\mathbf{H}_{3}$ : Level of education influences attitude towards social media marketing adoption.

\section{Time constraints}

For social media marketing initiatives to be successful, organisations need to give them enough time (Braun 2004). Time is needed to learn how the social networking site works, how other businesses in the same industry are using it for marketing, and how to present an attractive profile page. The time that businesses spend on social media sites in sending messages, attending to comments and blogging can be considerable. Braun (2004) and Au (2010) examined the adoption of new technologies by tourism businesses and revealed that time constraints and lack of understanding of how social media can be used for marketing strongly hinder the use of these technologies by tourism businesses. It is therefore hypothesised that:

$\mathbf{H}_{4}$ : Time constraints influence attitude towards social media marketing adoption.

\section{Perceived benefits and perceived usefulness}

Perceived usefulness is defined by Davis (1989) as the possibility that one is convinced that adopting a particular technology would improve the way one performs on a particular task (Davis 1989). In the context of this study, it can refer to the possibility that using social media marketing would improve the marketing performance of travel agencies and tour operators. If a company believes that a particular technology has desirable attributes that could improve their performance, they tend to develop a favourable attitude towards using it. Perceived benefit is a factor that can affect the intention of an enterprise to adopt the use of new Internet technologies (Alford \& Page 2015; Gitau \& Nzuki 2014; Wanyoike, Mukulu \& Waititu 2012). This study proposes that:

$\mathbf{H}_{5}$ : Perceived usefulness influences attitude towards social media marketing adoption.

\section{Perceived ease of use}

Gardner and Amoros (2004:2) defined perceived ease of use as 'the degree to which a system would be free of physical and 
mental efforts'. Porter and Donthu (2006:1001) highlighted the fact that 'individuals have specific beliefs about their performance capabilities based on a variety of individual experience and personality factors'. Perceived ease of use is associated with the 'user-friendliness' of the social website. Perceived ease of use, according to Ali, Mat and Ali (2015), is an important antecedent of users' adoption of e-commerce technologies. El-Gohary (2012) also concluded perceived ease of use influences decisions on the adoption of e-marketing. Perceived ease is also expected to influence the use of social media marketing. Thus, the following hypothesis is formulated:

$\mathbf{H}_{6}$ : Perceived ease of use influences attitude towards social media marketing adoption.

\section{External pressure}

SMMEs perceive new technology as a competitive tool which, when competitors adopt technologies to stay ahead, enables them quickly to 'jump unto the wagon and embrace the new technology' (El-Gohary 2012:1259). Previous studies concur that pressure from competitors is a factor that influences usage of new Internet technologies (El-Gohary 2012; Wanyoike et al. 2012). Wanyoike et al. (2012) examined how SMEs in Kenya use e-commerce and concluded that pressure from both competitors and customers determines to a certain extent the adoption of e-commerce. 'In the context of social media firms are likely to be induced to adopt social media because of the external pressure exerted from competitors and customers' (El-Gohary 2012:61). To determine whether external pressure has an influence on social media marketing usage, the following hypotheses were formulated:

$\mathbf{H}_{7}$ : Pressure from competitors explains the variance in social media marketing usage.

$\mathbf{H}_{\mathbf{8}}$ : Pressure from customers explains the variance in social media marketing usage.

\section{Attitude towards social media marketing}

Attitude is defined by Fishbein and Ajzen (1975) as the degree to which an individual is favourably or unfavourably inclined towards an object. To understand SMMEs' adoption of Internet technologies, researchers first need to investigate the attitude of owner manager, which determines their response towards those technologies (Shen 2015). If the owner or manager has an e-'vision' they will not hesitate to adopt and implement new Internet technologies.

Resistance to change is one of the most typical drawbacks in any attempts to bring about technological change, and e-commerce is no exception. The behavioural intention to adopt a new technology is influenced by the attitude towards that technology (Davis 1989). Praveena and Thomas (2014) and Shen (2015) concur that attitude is an important factor which influences intention to continue using Web technologies. Based on this discussion, the following two hypotheses were formulated:

$\mathbf{H}_{9}$ : Attitude towards adoption of social media explains the variance in level of social media marketing usage.
$\mathbf{H}_{10}$ : Attitude towards social media marketing usage positively influences intention to continue using social media marketing.

It is postulated in this study that technical knowledge or technical know-how will moderate the relationship between social media marketing usage and intention to continue using social media marketing. According to El-Gohary (2012) insufficient technical knowledge is one of the major inhibitors of e-commerce adoption among SMMEs. It is therefore posited in this study that:

$\mathbf{H}_{11}$ : The relationship between attitude towards social media marketing adoption and level of social media marketing usage is significantly moderated by technical knowledge.

Considering the theoretical background provided above, the following research framework is proposed for the study in Figure 3.

\section{Methodology}

An exploratory quantitative research design was used to conduct the survey. The study's population comprised all travel agencies and tour operators registered on the database of the Association of South African Travel Agencies (ASATA) and those registered in the Yellow Pages. The study focused on all provinces in South Africa, as the number of travel agencies and tour operators in South Africa is limited. A total of 1100 travel agencies were found, and the questionnaire was distributed through e-mail and telephonic interviews. An independent research consulting company was contacted to carry out the data collection process. Only those travel agencies using social media marketing were requested to complete the questionnaire for the researchers to examine social media marketing usage.

The respondents were asked to state their level of agreement with the statements provided regarding social media marketing usage. The questions used a five-point Likert scale, where 1 indicated 'strongly disagree' and 5 indicated 'strongly agree'. The items in the questionnaire were adopted from previous studies by Salwani et al. (2009), Wanyoike et al. (2012) and Gitau and Nzuki (2014),which investigated the use of e-commerce by tourism businesses and were adapted to suit the investigation of social media marketing usage. The first part of the questionnaire focused on demographic data, while the remainder focused on the use of social media marketing and contained items that sought to measure this. A list of the questionnaire items used for this study is found in Appendix 1 . To ensure validity, the study made sure that the content of the questionnaire supported the research objectives and measured the actual variable which the study intended to measure. Ten respondents were used in pilot testing, and the questionnaire design was found to be good enough to collect data that would be useful in achieving the research objective.

A total of 150 questionnaires were filled in correctly and were used for data analysis. For statistical analysis after data coding and editing, SPSS version 23 was used. The Cronbach's alpha test was performed to assess the reliability of the items. 


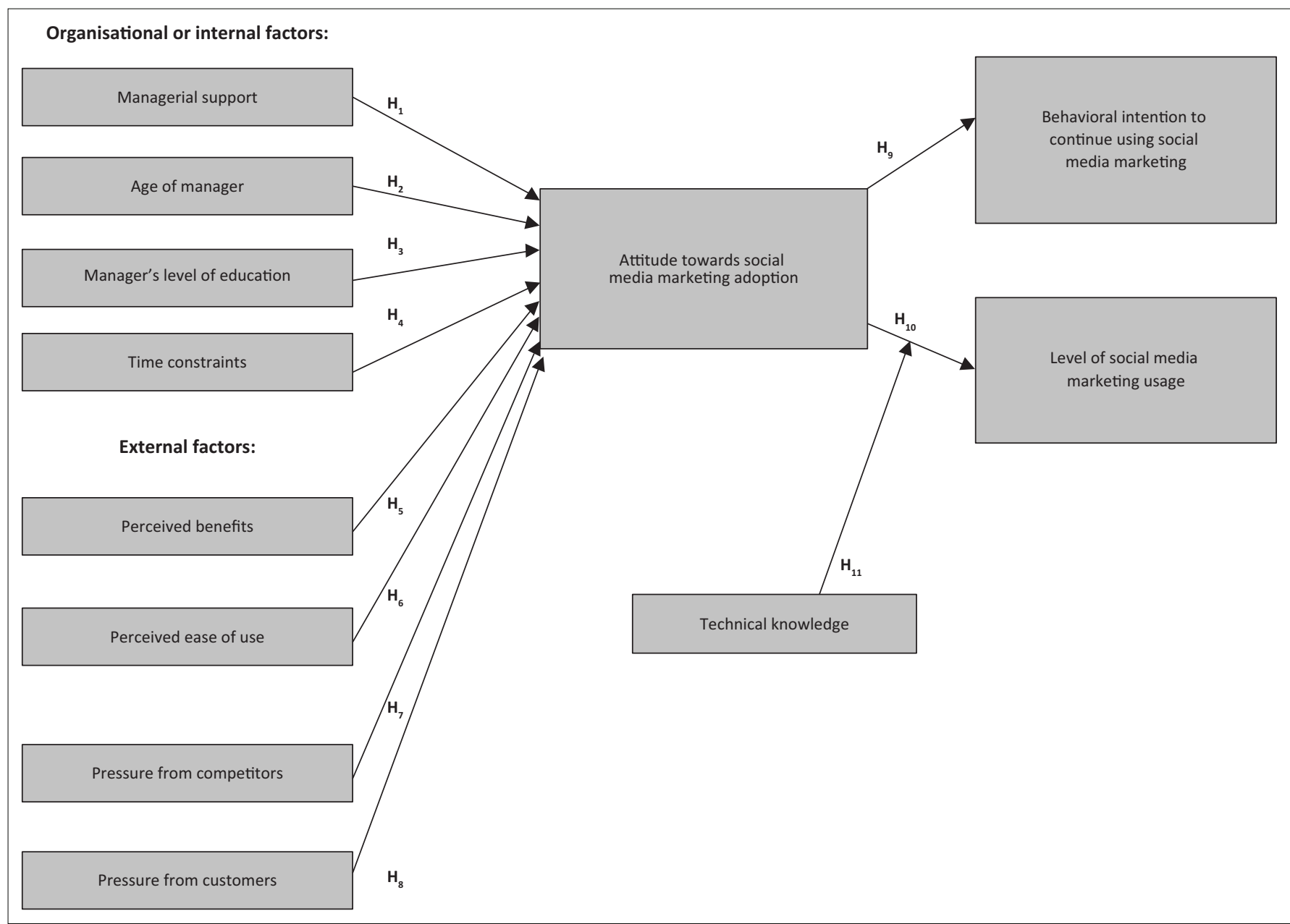

FIGURE 3: Proposed framework.

To test the hypotheses formulated for this study, linear regression analysis in conjunction with one-way ANOVA was used. $R$-squared values and $F$-test statistics were used to test the fitness of the model. Demographic information is presented in Table 1 on the results section.

\section{Results}

\section{Reliability results}

According to Hair et al. (2010), for constructs to be regarded as reliable, the alpha value should be greater than 0.6. The reliability results (Table 2 ) indicate alpha values greater than 0.6 for all the constructs.

To test the fitness of the model, Durbin-Watson adjusted $R^{2}$ and $F$ change values were used. For a regression model to be considered fit it must meet the assumption that there should be no serial correlation among the residuals (Lin \& Zhilin 2008). To check whether there was any serial correlation among the residuals, this study used DurbinWatson statistics. The Durbin-Watson values fall between 0 and 4 , and the closer the value is to 0 , the greater the positive serial correlation. A value above 2 shows that there is no serial correlation problem among the residuals (Field 2008). A Durbin-Watson value of 2.125 was obtained
TABLE 1: Demographic information.

\begin{tabular}{llcc}
\hline $\begin{array}{l}\text { Demographic } \\
\text { variable }\end{array}$ & Category & $\begin{array}{c}\text { Number of } \\
\text { respondents }\end{array}$ & $\begin{array}{c}\text { Valid percentage } \\
(\mathbf{\%})\end{array}$ \\
\hline Type of business & Tour operator & 35 & 23.3 \\
& Travel agent & 115 & 76.7 \\
Age & 25-30 years & 9 & 6.0 \\
& $31-35$ years & 23 & 15.3 \\
& 36-45 years & 58 & 38.7 \\
& 46-55 years & 47 & 31.8 \\
Qualification & 56 and above & 13 & 8.7 \\
& No matric certificate & 0 & 0 \\
& Matric certificate & 5 & 3.3 \\
& Diploma & 20 & 13.3 \\
& Bachelor's degree & 56 & 37.4 \\
& Honours degree & 63 & 42.0 \\
& Master's degree & 6 & 4.0 \\
& Doctoral degree & 0 & 0 \\
\hline
\end{tabular}

(Table 3), implying that the residuals were not serially correlated.

An $F$ value of 12.654 and sig. $F$ of 0.0002 were obtained (Table 3), indicating the model's goodness of fit. Field (2008) indicates that a model is regarded as fit if the $F$ change value is above 10 and the $R^{2}$ value close to 1 . In this case the $R^{2}$ value is 0.661 and the $F$ change value is 12.654 , implying that the model is fit. 


\section{One-way ANOVA}

One-way ANOVA was used to understand whether differences between respondents' attitude to social media marketing adoption were based on education level and age group. 'ANOVA is used for the case of a quantitative outcome with categorical variable that has two or more levels of treatment' (Fisher 1954). Accordingly, hypotheses 2 and 3 were tested using ANOVA, because categorical data were used. The results are shown in Table 4.

The ANOVA results (Table 4) show no significant variance in how different age groups view social media marketing adoption. This is indicated by a $p$ value greater than 0.05 (age $=0.310$ ). Thus, $\mathrm{H}_{2}$ is not accepted. On the other hand the results show a significant variance in how managers with different educational levels (education level $=0.001$ ) view social media marketing adoption. $\mathrm{H}_{3}$ is therefore

TABLE 2: Reliability results.

\begin{tabular}{lcc}
\hline Variable & Number of indicators & Cronbach's alpha \\
\hline Attitude & 4 & 0.683 \\
Behavioural intention & 3 & 0.746 \\
Level of usage & 6 & 0.637 \\
Managerial support & 3 & 0.806 \\
Pressure from competitors & 4 & 0.612 \\
Perceived ease of use & 3 & 0.776 \\
Pressure from customers & 3 & 0.675 \\
Perceived benefits & 4 & 0.859 \\
Time constraints & 3 & 0.687 \\
Technical knowledge & 3 & 0.701 \\
\hline
\end{tabular}

TABLE 3: Summary of the model.

\begin{tabular}{ccccccc}
\hline Model & \multicolumn{3}{c}{ Model } & \multicolumn{3}{c}{ Change statistics } \\
\cline { 2 - 7 } & $\boldsymbol{R}$ & $\boldsymbol{R}^{2}$ & $\begin{array}{c}\text { Adjusted } \\
\boldsymbol{R}^{2}\end{array}$ & $\begin{array}{c}\boldsymbol{F} \text { change } \\
\text { value }\end{array}$ & $\begin{array}{c}\text { Sig. } \\
\boldsymbol{F} \text { change }\end{array}$ & Durbin-Watson \\
\hline 1 & 0.831 & 0.661 & 0.622 & 12.654 & 0.0002 & 2.125 \\
\hline
\end{tabular}

$R$, Population means in hypotheses testing; $R^{2}$, is a statistical measure of how close the data are to the fitted regression line; Adjusted $R^{2}$, is a modified version of $R^{2}$ that has been adjusted for the number of predictors in the model; $F$ change, the improvement in $R^{2}$ when the second predictor is added; Sig. F, statistical significant value. accepted. Regression results for the other five hypotheses on factors affecting attitude towards social media adoption are presented in Table 5.

The regression results (Table 5) show that managerial support $(p=0.000)$, pressure from competitors $(p=0.001)$, perceived ease of use (0.003) and perceived benefits (0.046) have an influence on attitude towards social media marketing adoption. Accordingly $\mathrm{H}_{1}, \mathrm{H}_{5}, \mathrm{H}_{6}$ and $\mathrm{H}_{7}$ were accepted. On the other hand, time constraints (0.332) and pressure from customers (0.798) do not have significant influence on attitude towards social media marketing adoption. Therefore, $\mathrm{H}_{4}$ and $\mathrm{H}_{8}$ were not accepted. Regression analysis for hypotheses 10 and 11 was run separately from the other hypotheses since the dependent variable is different. The regression and the model summary results for each hypothesis are shown in Tables 6-9, respectively.

The standardised coefficient of attitude towards social media marketing adoption (Table 6 ) is 0.067 with a probability value of 0.001 , implying a strong relationship between attitude towards social media marketing adoption and intention to continue using social media marketing. Thus $\mathrm{H}_{10}$ was accepted. A sig $F$ value of 0.000 is obtained (Table 7 ) indicating goodness of model fit.

The standardised coefficient of attitude towards social media marketing adoption (Table 8 ) is 0.128 and the concomitant probability, as provided by the $F$-test, is 0.003 . This implies that attitude towards social media marketing adoption significantly influences level of social media marketing usage. Therefore, $\mathrm{H}_{11}$ was accepted. Furthermore the Sig. $F$ value of 0.001 obtained (Table 9) showing the goodness of fit of the model.

\section{Analysis of the moderating variable}

To test the effect of the moderating variables (technical knowledge), hierarchical regression analysis was conducted by

TABLE 4: ANOVA results.

\begin{tabular}{lcccc}
\hline Variable & Sum of squares & Df & Mean squares & S change \\
\hline Age & 1.613 & 1 & 1.613 & 1.045 \\
Education level & 10.873 & 1 & 10.873 & 0.310 \\
\hline
\end{tabular}

Note: Dependent variable: Attitude towards social media marketing adoption.

$\alpha=0.05$, confidence interval $=95 \%$.

Df, Degree of freedom; $F$ change, the improvement in $R^{2}$ when the second predictor is added; Sig., statistical significant value.

TABLE 5: Regression results.

\begin{tabular}{|c|c|c|c|c|c|}
\hline \multirow[t]{2}{*}{ Model 1: Variable } & \multicolumn{2}{|c|}{ Unstandardised coefficients } & \multirow{2}{*}{$\begin{array}{l}\text { Standardised coefficients } \\
\text { (Beta) }\end{array}$} & \multirow[t]{2}{*}{$\mathbf{T}$} & \multirow[t]{2}{*}{ Sig. } \\
\hline & B & Standard error & & & \\
\hline (Constant) & 1.156 & 0.647 & - & 1.786 & 0.076 \\
\hline MS & 0.386 & 0.097 & 0.498 & 4.272 & $0.000 * * *$ \\
\hline $\mathrm{T}$ & 0.056 & 0.058 & 0.075 & 0.973 & 0.332 \\
\hline PC & 0.021 & 0.082 & 0.020 & 0.256 & 0.798 \\
\hline PFC & 0.286 & 0.091 & 0.254 & 3.796 & $0.001 * * *$ \\
\hline PB & 0.183 & 0.091 & 0.169 & 2.010 & $0.046 *$ \\
\hline
\end{tabular}

Note: Dependent variable: Attitude towards social media adoption

$*$, Significant at $10 \% ; * *$, significant at $5 \%$; **, significant at $1 \%$.

MS, managerial support; T, time; PC, pressure from customers; PFC, pressure from competitors; PEU, perceived ease of use; PB, perceived benefits; Sig. significance. 
TABLE 6: Regression extracts for hypothesis 10.

\begin{tabular}{lcc}
\hline Model 1 & Standardised coefficient & Sig. \\
\hline Constant & - & 0.000 \\
$\begin{array}{l}\text { Attitude towards social } \\
\text { media marketing }\end{array}$ & 0.067 & 0.001 \\
\hline
\end{tabular}

Sig., significance

Note: Dependent variable: Intention to continue using social media marketing

TABLE 7: Summary of the model for Hypotheses 10.

\begin{tabular}{lccccc}
\hline $\boldsymbol{R}$ & $\boldsymbol{R}^{\mathbf{2}}$ & Adjusted $\boldsymbol{R}^{2}$ & $\boldsymbol{F}$ change & Sig. $\boldsymbol{F}$ & Durbin-Watson \\
\hline 0.658 & 0.467 & 0.397 & 12.459 & 0.000 & 2.312 \\
\hline
\end{tabular}

$R$, Population means in hypotheses testing; $R^{2}$, is a statistical measure of how close the dat are to the fitted regression line; Adjusted $R^{2}$, is a modified version of $R^{2}$ that has been adjusted for the number of predictors in the model; $F$ change, the improvement in R-square when the second predictor is added; Sig. $F$, statistical significant value.

TABLE 8: Regression extracts for Hypothesis 11.

\begin{tabular}{lcc}
\hline Model 1 & Standardised coefficient & Sig. \\
\hline Constant & - & 0.000 \\
$\begin{array}{l}\text { Attitude towards social } \\
\text { media marketing }\end{array}$ & 0.128 & 0.003 \\
\hline
\end{tabular}

Sig., significance

Note: Dependent variable: Level of social media marketing usage.

TABLE 9: Summary of the model for hypothesis 11.

\begin{tabular}{lccccc}
\hline $\boldsymbol{R}$ & $\boldsymbol{R}^{2}$ & Adjusted $\boldsymbol{R}^{2}$ & $\boldsymbol{F}$ change & Sig. $\boldsymbol{F}$ & Durbin-Watson \\
\hline 0.678 & 0.525 & 0.412 & 11.023 & 0.001 & 2.001 \\
\hline
\end{tabular}

$R$, Population means in hypotheses testing; $R^{2}$, is a statistical measure of how close the data are to the fitted regression line; Adjusted $R^{2}$, is a modified version of $R^{2}$ that has been adjusted for the number of predictors in the model; $F$ change the improvement in $R$-square when the second predictor is added; Sig. F, statistical significant value.

adding the new factor (technical knowledge) to the model. According to Field (2008), if a new term is added the $R^{2}$ value will change, and for a variable to be considered as a moderator, the change in the $\mathrm{R}^{2}$ should be more than 3\% (Wen, Hau \& Chang 2005). In this study, when technical knowledge was added to the equation model of relationship between attitude towards social media marketing adoption and level of social media marketing usage, an increase of $4.5 \%$ in the $R^{2}$ was realised. The initial $R^{2}$ value (Table 9) was 0.525 , and when the moderating value was added in the equation the $R^{2}$ value changed to 0.570 , showing a $4.5 \%$ increase. This implies that technical knowledge moderates the relationship between attitude towards social media marketing adoption and level of social media marketing usage, which provides additional support for accepting hypothesis 11 .

\section{Discussion}

The results from this study show that managerial support influences attitude towards social media marketing adoption. This means that if top management supports the idea of adopting new technologies, the whole organisation's attitude towards new technology adoption will be positive. This is consistent with previous studies: Dahnil et al. (2014) concluded that top management influences attitude towards the adoption of e-commerce projects, while Salwani et al. (2009) and Matikiti et al. (2012) found that managerial support influences the adoption and implementation of e-commerce initiatives and Internet technology.

This study also confirms that pressure from competitors influences attitude towards social media marketing adoption. This is consistent with the findings of Wanyoike et al. (2012) and El-Gohary (2012), who also concluded that external pressure from competitors influences the adoption of new technologies by SMMEs in tourism. Contrary to the findings of previous studies (El-Gohary 2012), this study could not establish a relationship between pressure from customers and attitude towards the adoption of social media marketing.

The results also show that perceived benefits influence attitude towards the adoption of social media marketing by travel agents and tour operators. If people perceive that using social media marketing will bring some benefits or give the business a competitive edge, their attitude towards adopting social media will be positive. Similarly, Gitau and Nzuki (2014), in their analysis of the determinants of new technology adoption, concluded that perceived usefulness influences the adoption of mobile technologies. Alford and Page (2015) found that the primary motivation for SMMEs to adopt new technologies is their expected benefits. The results of the present study also revealed that perceived ease of use affects attitude towards the adoption of social media marketing. This is in line with the findings of Ali et al. (2015), in their study on the conceptual framework for an e-commerce adoption model, that perceived ease of use determines the adoption of e-commerce.

This study also revealed that managerial characteristics such as educational level influence attitude towards the adoption of social media marketing in the South African travel agent and tour operator industry. This is consistent with the findings of Aspasia and Ourania (2014) and Cox (2010), which revealed that the education level of managers has a significant impact on the use of social media tools. On the other hand, no relationship was found between the age of the manager and attitude towards social media marketing adoption. This is contrary to the findings of Cox (2010), which found a relationship between managerial characteristics, such as age and attitude towards social media usage. However, the result in the present study is similar to the findings of Gong (2012), which could not establish any relationship between the age of the manager and attitude towards the adoption of social media marketing.

Contrary to the findings of Matikiti et al. (2012), this study could not find a relationship between time and attitudes towards social media marketing adoption. The reason could be that the study by Matikiti et al. (2012) focused on the utilisation of Internet marketing as a whole, while the current study focused only on a specific type of Internet technology, namely, social media.

The study also confirms that attitudes towards social media marketing influence intention to continue using social media marketing. If the organisation has a positive attitude towards social media marketing adoption, they will want to continue using it. This is in line with the findings of Praveena and Thomas (2014) and Shen (2015), who concluded that there is a positive relationship between attitude and the intention to continue using social media websites. 
The results of the study also revealed that the relationship between attitude towards social media marketing and level of social media marketing usage is moderated by technical knowledge (know-how). This means that even if the management supports social media marketing, the availability of skilled personnel who have knowledge of how to implement social media marketing effectively will determine the extent to which the organisation utilises social media marketing. In the problem statement it was highlighted that SMMEs are lagging behind in the adopting of social media marketing. The most probable reason might be that they lack the technical knowledge of using social media tools to effectively market their products or services.

From an academic perspective, this study provides an understanding of how social media marketing is being used in small tourism businesses. In addition, the study validates the applicability of the TOE and TAM frameworks in analysing the use of social media marketing by small businesses. The study proposes a moderating variable in the relationship between attitude towards social media marketing and level of social media marketing usage. This study confirms that TOE and TAM are among the most important theories to explain the adoption of Internet technologies. TOE posits the influence of external and internal factors on management's decision to adopt new technologies. It was revealed in this study that top management support and the manager's education level influence the adoption of social media marketing. All this might help to explain why SMMEs are sometimes lagging behind in adopting social media marketing. Considering this, the following guidelines are proposed.

\section{Guideline 1}

It is recommended that management should encourage the adoption of social media marketing so that their subordinates will view social media marketing in a positive manner. It is suggested that management facilitate the training of employees, especially those responsible for the marketing of products and services, so that they will be able to acquire the skills required in performing social media marketing. Management could also encourage employees to freely contribute their ideas on the business profile page, as this would allow the one responsible for social media marketing to obtain rich and diverse information to craft a strong social media strategy. The management or owner of a tour operator or travel agency brand or business should also encourage or offer an opportunity to their employees to further their education (i.e. provide incentives such as study leave to gain power through knowledge). This could positively influence attitudes towards the adoption of social media as the results of this study confirm that education level influences social media marketing adoption.

\section{Guideline 2}

Management is encouraged to keep an eye on how competitors are performing in social media marketing to improve their own performance in this respect. Reading marketing reports from other competitors can also assist management to understand how competitors are utilising social media marketing.

\section{Guideline 3}

The results show that technical knowledge has a moderating effect on the relationship between attitude towards social media marketing and level of usage. Government and industry associations can play a pivotal role by creating awareness and rendering assistance to SMMEs on how to use social media marketing. For instance, the Association of South African Travel Agents (ASATA) can provide training for its members on how to use social media marketing so that they may utilise it effectively. Governments can also conduct workshops on social media marketing and their benefits so that employees and management in the tourism industry will appreciate the benefits of this new technology for marketing.

\section{Guideline 4}

To maintain their competitiveness, travel agencies and tour operators that are at an advanced stage of social media marketing need to hire IT specialists who have sufficient knowledge of how social media can be used. Social media tools are continuously evolving, and IT personnel may assist the business to learn about new social media tools quickly by providing them with advice on how the social media tool can be operated.

\section{Guideline 5}

Social media website service providers should strive to make their websites as user-friendly as possible, as this will create a positive intention to continue using the website.

\section{Limitations and areas of further research}

This study focused only on small tourism businesses (travel agencies and tour operators), which may not give a true reflection of social media marketing adoption in the South African tourism industry. There is a need to focus on other businesses in tourism, such as chain hotels and lodges.

Social media marketing implementation is time dimensional so should be measured over time. The results of this study can give only a snapshot of what is happening in the tourism industry, whereas a longitudinal study will give an indication of what is happening over a period of time.

\section{Conclusion}

The main aim of the study was to examine factors which influence attitude towards the adoption of social media marketing as well as to establish whether technical knowledge moderates the relationship between attitude towards social media marketing and level of social media marketing usage. The study used the TOE framework and TAM model to identify these factors. The results confirmed that external and internal factors such as pressure from competitors and 
managerial characteristics do influence attitude towards the use of social media marketing. It is concluded that TAM variables such as perceived usefulness and perceived benefits play a significant role in influencing attitude towards social media marketing adoption. Lastly, the study confirms that the relationship between level of social media marketing usage and attitude towards social media usage is moderated by technical knowledge.

\section{Acknowledgements Competing interests}

The authors declare that they have no financial or personal relationships which may have inappropriately influenced them in writing this article.

\section{Authors contributions}

All authors contributed to the writing and research of this article.

\section{References}

Abou-Shouk, M.A., Lim, M.W. \& Megicks, P., 2016, 'Using competing models to evaluate the role of environmental pressures in ecommerce adoption by smal and medium sized travel agents in a developing country', Tourism Managemen 52, 327-339. https://doi.org/10.1016/j.tourman.2015.07.007

Alford, P. \& Page, S.J., 2015, 'Marketing technology for adoption by small business', The Service Industries Journal 35(11/12), 655-669. https://doi.org/10.1080/0264 2069.2015.1062884

Ali, N.M., Mat., N.K.N. \& Ali, N.M., 2015, 'The conceptual framework for e-commerce adoption model', American Journal of Economics 5(2), 148-154.

Aspasia, V. \& Ourania, N., 2014, 'Social media adoption and managers' perceptions', International Journal on Strategic Innovative Marketing 1, 61-73. https://doi. International Journal on Strategic
org/10.15556/IJSIM.01.02.001

$\mathrm{Au}, \mathrm{A}$., 2010, 'Adoption of Web 2.0 by tourism businesses in NSW', Tourism New South Wales, viewed 10 July 2016, from http://www.egov.vic.gov.au/.../new-southwales/...new-south-wales/...tourist

Baker, F., 2012, 'The Technology-Organization-Environment framework', in Y.K. Dwivedi, M.R. Wade \& S.L. Schneberger (eds.), Information systems theory: Explaining and predicting our digital society, vol. 1, pp. 231-245, Springer, New York.

Braun, P., 2004, 'Regional tourism networks: The nexus between ICT diffusion and change in Australia', Information Technology \& Tourism 6(4), 231-243. https://doi. org/10.3727/1098305032781139

Chao, C.A. \& Chandra, A., 2012, 'Impact of owner's knowledge of information technology (IT) on strategic alignment and IT adoption in US small firms', Journa of Small Business and Enterprise Development 19(1), 114-131. https://doi. org/10.1108/14626001211196433

Chmielecki, M., 2014, 'The use of Facebook for marketing purposes among SMEs as a modern marketing method-Research results from Poland', Lviv Polytechnic National University Institutional Repository, viewed 12 June 2016, from http:// ena.Ip.edu.ua:8080/bitstream/ntb/26116/1/30-207-217.pdf

Cox, S.A., 2010, 'Online social network member attitude towards online advertising formats', MA thesis, The Rochester Institute of Technology, New York.

Dahnil, M.L., Marzuki, K.M., Langgat, J. \& Fabeil, N.F., 2014, 'Factors influencing SMEs adoption of social media marketing', Procedia - Social and Behavioral Sciences 148, 119-126. https://doi.org/10.1016/j.sbspro.2014.07.025

Davis, F.D., 1989, 'Perceived usefulness, perceived ease of use and user acceptance of information technology', MIS Quarterly 13(2), 319-340. https://doi.org/ 10.2307/249008

El-Gohary, H., 2012, 'Factors affecting e-marketing adoption and implementation in tourism firms: An empirical investigation of Egyptian small tourism organisations', Tourism Management 33(5), 1256-1269. https://doi.org/10.1016/j.tourman.2011. Tourism
10.013

Field, A., 2008, 'Multiple regressions using SSPS/PASW', Research methods in psychology: Multiple regressions, module C8057, University of Sussex, Brighton, viewed 10 July 2016, from http://www.statisticshell.com/ocd/pff

Fishbein, M. \& Ajzen, I., 1975, Belief, attitude, intention and behaviour: An introduction to theory and research, Addison-Wesley, Reading, MA.

Fisher, R.A., 1954, Statistical methods for research workers, 12th edn., Oliver \& Boyd Edinburgh.

Gardner, C. \& Amoros, D.L., 2004,'Development of an instrument to measure the acceptance of internet technology by consumers', paper presented at the 37th Hawaii International Conference on System Sciences, Big Island, Hawaii, 5-8th July.

Gitau, L. \& Nzuki, D., 2014, 'Analysis of determinants of m-commerce adoption by online consumers', International Journal of Business, Humanities and Technology $4(3), 88-94$

Gong, W., 2012, 'Factors influencing perceptions toward social networking websites in China', in M. Strano, H. Hrachovec, F. Cudweeds \& C. Ess (eds.), Cultural attitudes towards technology and communication 2012, proceedings of the 8th International CATaC Conference, Aarhus, Denmark, June 18-20, pp. 420-429.

Hair, J., Black, W., Babin, B. \& Anderson, R., 2010, Multivariate data analysis, 7th edn., Prentice-Hall, Upper Saddle River, NJ.

Hoti, E., 2015, 'The technological, organizational and environmental framework of IS innovation adaption in small and medium enterprises: Evidence from research over the last 10 years', International Journal of Business and Management 3(4), 1-14. https://doi.org/10.20472/BM.2015.3.4.001

Järvinen, J., Tollinen, A., Karjaluoto, H. \& Jayawardhena, C., 2012, 'Digital and social media marketing usage in B2B industrial section', Marketing Management Journal 22(2), 102-117.

Jones, N., Borgman, R. \& Ulusoy, E., 2015, 'The impact of social media on small tourism business', Journal of Small Business \& Enterprise Development 22(4), 611-632. https://doi.org/10.1108/JSBED-09-2013-0133

Kaplan, A.M. \& Haenlein, M., 2010, 'Users of the world, unite! The challenges and opportunities of social media', Business Horizons 53(1), 59-68. https://doi. org/10.1016/j.bushor.2009.09.003

Kim, H.D., Lee, I. \& Lee, C.K., 2011, 'Building Web 2.0 enterprises: A study of small and medium enterprises in the United States', International Small Business Journal 29, 1-19.

Kirtis, A.K. \& Karahan, F.B., 2011, 'To be or not to be in social media arena as the most cost efficient marketing strategy after the global recession', ProcediaSocial and Behavioral Sciences 24, 260-268. https://doi.org/10.1016/j. sbspro.2011.09.083

Lin, C. \& Zhilin, Q., 2008, 'What influences the company's economic value added? Empirical evidence from China's securities market', Management Science Engineering 2(1), 66-76.

Matikiti, R., Afolabi, B. \& Smith, W., 2012, 'An empirical evidence on the usage of internet marketing in the hospitality sector in an emerging economy and its relationship to profitability', International Review of Social Sciences and Humanities 4(1), 181-197.

Meske, C. \& Stieglitz, S., 2013, 'Adoption and use of social media in small and mediumsized enterprises', in F. Harmsen \& H. Proper (eds.), Practice-driven research on enterprise transformation, pp. 61-75, Springer, Berlin.

Ndekwa, A.G. \& Katunzi, T.M., 2016, 'Small and medium tourist enterprises and social media adoption: Empirical evidence from Tanzanian tourism sector', International Journal of Business and Management 11(4), 71-80. https://doi.org/10.5539/ijbm v11n4p71

Nguyen, T.U.H., 2009, 'Information technology adoption in SMEs: An integrated framework', International Journal of Entrepreneurial Behaviour and Research 15(2), 162-186. https://doi.org/10.1108/13552550910944566

Oliveira, T. \& Martins, M.F., 2011, 'Literature review of information technology adoption models at firm level', The Electronic Journal of Information System adoption models at firm
Evaluation 14(1), 110-121.

Porter, C.E. \& Donthu, N., 2006, 'Using the technology acceptance model to explain how attitudes determine Internet usage: The role of perceived access barriers and demographics', Journal of Business Research 59, 999-1007. https://doi. org/10.1016/j.jbusres.2006.06.003

Praveena, K. \& Thomas, S., 2014, 'Continuance intention to use Facebook: A study of perceived enjoyment and TAM', International Journal of Industrial Engineering and Management 4(1), 24-29.

Rogers, E.M., 1995, Diffusion of innovations, 4th edn., The Free Press, New York.

Sago, B., 2013, 'Factors influencing social media adoption and frequency of use: An examination of Facebook, Twitter, Pinterest and Google+', International Journal of Business and Commerce 3(1), 1-14.

Salwani, M.I., Marthandan, G., Norzaidi, M.D. \& Chong, S.C., 2009, 'E-commerce usage and business performance in the Malaysian tourism sector: Empirical analysis', Information Management \& Computer Security 17(2), 166-185. https:// doi.org/10.1108/09685220910964027

Seth, G., 2012, 'Analyzing the effects of social media on the hospitality industry', UNLV Theses/Dissertations/Professional Papers/Capstones, Paper 1346, University of Nevada, Las Vegas, NV.

Shen, G.C., 2015, 'How quality of life affects intention to use social networking sites: Moderating role of self-disclosure', Journal of Electronic Commerce Research 16(4), 276-289.

Starbuck, W.H., 1976, Organizations and their environments, Rand McNally, Chicago, IL.

Tarafdar, M. \& Vaidya, S.D., 2006, 'Challenges in the adoption of e-commerce technologies in India: The role of organizational factors', International Journal of Information Management 26(6), 428-441. https://doi.org/10.1016/j.ijinfomgt. 2006.08.001

Thompson, J.D., 1967, Organizations in action, McGraw-Hill, New York.

Tornatzky, L.G. \& Fleischer, M., 1990, Process of technology innovation, Lexington Books, Lexington, MA.

Verheyden, M. \& Goeman, K., 2013, 'Does company size matter? Differences in social media usage for business purposes', Journal of Applied Sciences 8(4), 1-15. 
Viljoen, K. \& Roberts-Lombard, M., 2016, 'Customer retention strategies for disintermediated travel agents: How to stop customers from migrating to online https://doi.org/10.19030/jabr.v32i2.9595

Wamba, S.F. \& Carter, L., 2014, 'Social media tools adoption and use by SMEs: An empirical study', Journal of End User and Organizational Computing 26(2), 1-17. https://doi.org/10.4018/joeuc.2014040101

Wanyoike, D.M., Mukulu, E. \& Waititu, A.G., 2012, 'ICT attributes as determinants of e-commerce adoption by formal small enterprises in urban Kenya', International Journal of Business and Social Science 3(23), 65-74.

Wen, Z., Hau, K. \& Chang, C., 2005, 'A comparison of moderator and mediator and their applications', Acta Psychological Sanica 37(2), 268-274.
World Travel \& Tourism Council, 2015, Travel \& Tourism economic impact 2015 world viewed 09 August 2016, from https://www.wttc.org//media/files/reports/ economic $\% 20$ impact $\% 20$ research/regional $\% 20$

Wu, I.L., Li, J.Y. \& Fu, C.Y., 2011, 'The adoption of mobile healthcare by hospital's professionals: An integrative perspective', Decision Support Systems 51(3), 587-596. https://doi.org/10.1016/j.dss.2011.03.003

Yazdanifard, R. \& Yee, L.T., 2014, 'Impact of social networking sites on hospitality and tourism industries', Global Journal of Human-Social Science 14(8), 1-6.

Zhu, K. \& Kraemer, K.L., 2005, 'Post-adoption variations in usage and value of e business by organisations: Cross-country evidence from the retails industry, Information Systems Research 16(1), 61-84. https://doi.org/10.1287/isre.1050. 0045

Appendix starts on the next page $\rightarrow$ 


\section{Appendix 1:}

TABLE 1-A1: Questionnaire items.

\begin{tabular}{lc}
\hline Item & Source
\end{tabular}

Managerial support

- Management emphasises the use of social media marketing

- Top management shows a lot of interest in social media marketing

- Top management is supportive of social media marketing

Attitude

- Use of social media marketing is good

Davis (1989)

- Our company has a positive feeling towards social media marketing

- Use of social media marketing is worthwhile

- The thought of using social media marketing is appealing

Time

$\mathrm{Au}$ (2010); Salwani et al. (2009)

- Using social media is too time consuming

- We cannot commit time to sustain social media marketing initiatives

- The time needed for social media marketing is too much for our company

Pressure from customers

- Our customers expects us to use social media

- Our customer demands that we use social media marketing

- Use of social media marketing is something that would make our customers happy

- We believe that our customers are ready to engage with us on social media

Perceived ease of use

Gitau and Nzuki (2014); Porter and Donthu (2006)

- Used of social media marketing is easy

- Our company can successfully implement social media marketing

- Using social media for marketing is not too complex

Perceived benefits

Porter and Donthu (2006)

- Social media marketing can help a company easily reach a lot of customers

- Social media marketing is relatively cheaper than traditional marketing media

- Social media marketing helps companies improve customers service

- Use of social media marketing increases company's ability to compete with others

Pressure from competitors

Salwani et al. (2009); Wanyoike et al. (2012)

- Our competitors have adopted social media marketing

- Our competitors are doing well in social media marketing

- Customers prefer businesses which use social media marketing

Technical knowledge

- We have adequate expertise for social media marketing

- We have skilled people in social media marketing

- We have people with knowledge of using social media marketing

- There are experts who are readily available to perform social media marketing on our behalf

- We can readily get support or advice on how to use social media for marketing

- We can easily get other companies to train us on the use of social media marketing

Level of usage

Zhu and Kraemer (2005)

- Our company has a broad social media marketing policy

- Our company has a specific social media marketing guidelines

- Our company monitors social media marketing usage

- Our company measures social media marketing Key Performance Indicators

- Our company frequently interacts with customers on social media

- Our company provides a number of links from the main social network page to other important sites

Behavioural intention to continue using social media marketing

- Our company will continue to use social media marketing

- Our company is planning to increase our social media marketing budget

- We intend to adopt more social media sites for marketing 